Revista Eletrônica Geografar, Curitiba, v. 2, Resumos do VI Seminário Interno de Pós-Graduação em Geografia, p. 37-37. Junho/2007

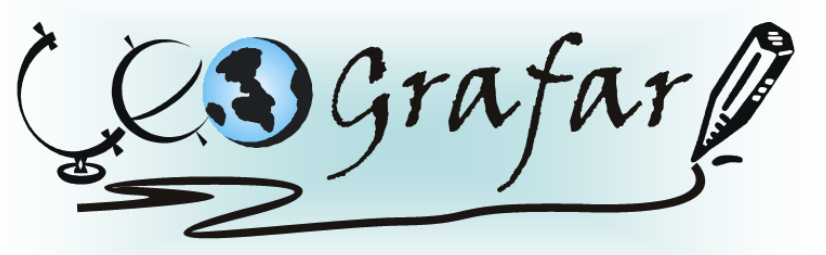

Revista Eletrônica do Programa de Pós-Graduação em Geografia - UFPR

\title{
EVOLUÇÃO GEOMORFOLÓGICA DO TERCEIRO PLANALTO PARANAENSE
}

\author{
JOSÉ MAURO PALHARES ${ }^{1}$
}

Esta pesquisa será realizada no Terceiro Planalto do Estado do Paraná, localizado na Região Sul do Brasil, cortado ao norte pelo Trópico de Capricórnio, possuindo 1/4 do seu território na zona tropical e o restante na zona temperada do Sul. Localizado entre as

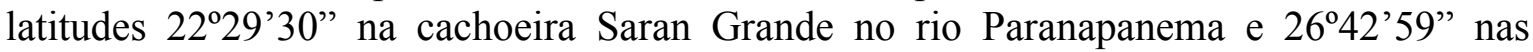
nascentes do rio Jangada, e entre as longitudes a oeste de Greenwich de $48^{\circ} 02^{\prime}$ ' $24^{\prime \prime}$ no rio Ararapira e $54^{\circ} 37^{\prime} 38^{\prime \prime}$ no município de Foz do Iguaçu. Devido à posição geográfica ocupada pelo Paraná em relação à Região Sul e às demais regiões brasileiras, à América do Sul e o Globo Terrestre, apresenta uma grande variação nos aspectos relacionados à cobertura vegetal, solos, hidrografia, climas, com uma diferenciada formação geológica e geomorfológica. É relevante o entendimento das interações existentes entre as suas regiões naturais. Portanto, o objetivo do trabalho consiste no levantamento de dados para uma análise dos aspectos físicos (clima, vegetação, hidrografia, relevo e geologia) do terceiro planalto paranaense. Determinando com isso, as principais causas dos processos atuantes na dinâmica paisagística desse compartimento, configuração de sua origem, evolução geomorfológica continental, drenagem superficial e das relações ocorridas ao longo do tempo em particular no que diz respeito ao papel do paleoclima a partir do cenozóico. $\mathrm{O}$ Terceiro Planalto é o maior dos compartimentos geomorfológicos do Estado, limitado a leste pela Escarpa triássico-jurássica estendendo-se para o oeste até o rio Paraná. As rochas predominantes são basaltos (rochas magmáticas extrusivas) e arenitos (rochas sedimentares, principalmente da era mesozóica). A metodologia usada no desenvolvimento deste trabalho será elaborada pelos pesquisadores (professor e orientando).

Palavras-Chave: Terceiro planalto paranaense, geomorfologia, quaternário.

'Doutorando em Geografia - UFPR - email: zepalhares@bol.com.br ou www.geopalhares.com.br Orientador: EVERTON PASSOS 